\title{
Lactate Dehydrogenase Activity and Isoenzyme Patterns in Skeletal Muscle, Fat, Exocrine Pancreas and Isolated Pancreatic Islets of Normal and Obese-Hyperglycaemic Mice
}

\author{
B. Prochazka, M.A. Qureshi and A.J. Matty
}

Department of Biological Sciences, The University of Aston in Birmingham, U.K., and 4th Medical Clinic, Charles University, Prague, Czechoslovakia

Received: August 27, 1969

Summary. The total lactate dehydrogenase (LDH) activity and $\mathrm{LDH}$ isoenzyme patterns of isolated pancreatic islets, acinar pancreas, fat tissue and skeletal muscle from mice with obese-hyperglycaemic syndrome were compared with those of corresponding tissues from lean littermates. - The pancreatic tissues of obesehyperglycaemic animals exhibited higher LDH activity than corresponding tissues of normal animals. This increase in LDH activity was not parallel in islets and acinar tissue. - No significant difference in the $\mathrm{LDH}$ activity of either skeletal muscle or fat tissue between the two groups of animals was found. - In animals with obese-hyperglycaemic syndrome, LDH isoenzyme patterns of pancreatic islets, acinar pancreas and fat showed LDH 5 increase and LDH 4 decrease. LDH isoenzyme patterns of skeletal muscle showed the decrease of LDH 5 percentage. - The LDH 1, LDH 2 and LDH 3 percentages of the fat tissue were lower in animals with obese-hyperglycaemic syndrome, but those of the skeletal muscle were lower in normal animals. - Results presented are consistent with the opinion that in obese-hyperglycaemic mice both endocrine and exocrine pancreatic tissues as well as fat tend to have an increase in the proportion of glycolysis in their intermediary metabolism, whereas the reverse tendency - towards an increase in the proportion of oxidative pathways - is valid for skeletal muscle.

Activité de la lactate déshydrogénase et répartition des isoenzymes dans le muscle strié, le tissu adipeux, le pancréas exocrine et les îlots pancréatiques isolés de souris normales et obèse-hyperglycémiques

Résumé. L'activité de la lactate déshydrogénase totale (LDH) et la répartition des isoenzymes de la $\mathrm{LDH}$ dans les îlots pancréatiques isolés, le pancréas acineux, le tissu adipeux et le muscle strié de souris ayant un syndrome obèse-hyperglycémique, ont été comparées avec celles des tissus correspondants de souris non-obèses de mêmes parents. - Les tissus pancréatiques des animaux obèsehyperglycémiques montraient une activité LDH plus élevée que les tissus correspondants des animaux normaux. Cette augmentation de l'activité de la LDH n'était pas parallèle dans les îlots et le tissu acineux. - On n'a trouvé aucune différence significative dans l'activité de la LDH du muscle strié ou du tissu adipeux entre les deux groupes d'animaux. - Chez les animaux ayant un syndrome obèse-hyperglycémique, la répartition des isoenzymes de la LDH dans les îlots pancréatiques, le pancréas acineux et le tissu adipeux, montrait une augmentation de la $\mathrm{LDH} 5$ et une diminution de la $\mathrm{LDH} 4$. La répartition des isoenzymes de la LDH du muscle strié montrait une di- minution du pourcentage de la LDH 5. - Les pourcentages de LDH 1, de LDH 2 et de LDH 3 du tissu adipeux étaient plus bas chez les animaux ayant un syndrome obèse-hyperglycémique, mais ceux du muscle strié étaient plus bas chez les animaux normaux. - Les résultats présentés sont en concordance avec l'opinion que chez les souris obèse-hyperglycémiques, à la fois les tissus pancréatiques endocrine et exocrine ainsi que le tissu adipeux, ont tendance à avoir une augmentation de la proportion de glycolyse dans leur métabolisme intermédiaire, alors que la tendance inverse - augmentation de la proportion des voies oxydatives - est valable pour le muscle strié.

Die Aktivität der Lactat-Dehydrogenase und die Verteilung der Isoenzyme im Skeletmuskel, Fett, exokrinem Pankreas und isolierten Pankreasinseln von normalen und fettsüchtigen-hyperglykämischen Mäusen

Zusammenfassung. Die Gesamt-Lactat-Dehydrogenase-Aktivität (LDH) und die LDH-Isoenzymverteilung in isolierten Pankreasinseln, azinösem Pankreas, Fettgewebe und Skeletmuskel von Mäusen mit fettsüchtighyperglykämischem Syndrom wurden mit denen in den entsprechenden Geweben von mageren Wurfgeschwistern verglichen. - Im Pankreasgowebe der fettsüchtig. hyperglykämischen Tiere fand sich eine höhere LDH. Aktivität als im Vergleichsgewebe der Normaltiere. Der Anstieg der LDH.Aktivität verlief in den Inseln und dem Azinus-Gewebe nicht parallel. - Zwischen der LDH. Aktivität des Skeletmuskels und des Fettgewebes bei den beiden Tierkollektiven fand sich keine signifikante Differenz. - Bei den Tieren mit fettsüichtig-hyperglykämischem Syndrom zeigte die LDH-Isoenzymverteilung in Pankreasinseln, azinösem. Pankreas und Fett einen Anstieg der LDH 5 und einen Rückgang der LDH 4. In der Skeletmuskulatur fand sich ein Absinken des LDH-5 Anteils. Im Fettgewebe waren die LDH-1, LDH-2 und LDH-3 Anteile bei den Tieren mit fettsüchtig-hyperglykämischem Syndrom niedriger, das Gleiche war in der Skeletmuskulatur der Normaltiere der Fall. - Die hier vorgelegten Resultate stimmen mit der Hypothese überein, daß bei fettsüchtig-hyperglykämischen Mäusen der Anteil der Glykolyse im Intermediärstoffwechsel im endokrinen und exokrinen Pankreasgewebe und im Fettgewebe eher erhöht ist, während die umgekehrte Tendenz - in Richtung eines Anstiegs des Anteils der oxydativen Abbauwege - für den Skeletmuskel gilt.

Key-words: Differences, mice, obese hyperglycaemic syndrome, lean littermates, $\mathrm{LDH}$ activity, spectrophotometry, isoenzyme patterns, electrophoresis, exocrine pancreas, islets, fat, skeletal muscle.
The metabolic disorders of the obese-hyperglycaemic syndrome in mice have been extensively studied, but despite these studies little is known of possible defects of intermediary cellular metabolism. One avenue of exploring intermediary cell metabolism is to study the ratio of aerobic to anaerobic pathways in energy supply by determining lactate dehydrogenase (LDH) isoenzyme patterns. The $\mathrm{LDH}$ isoenzyme 
pattern represents a suitable criterion for the identification of type of energy production, and any changes in isoenzyme pattern probably indicate an alteration of the tissue metabolism.

Lactate dehydrogenase (l-lactate:nicotinamideadenine dinucleotide oxidoreductase, EC. 1.1.1.27) consists of several different fractions, isoenzymes $[21,14,20]$. The basis of the LDH heterogeneity is explained by the tetramer hypothesis $[1,2]$. Although they catalyze the same reaction, LDH isoenzymes differ from each other in a number of properties, among them kinetic properties $[23,13]$. The difference in kinetic properties of an isoenzyme can be correlated with the type of cellular metabolism [5], LDH 1 is involved in aerobic metabolic type of tissue - producing energy mostly by oxidative cycles particularly the citric acid cycle, whereas LDH 5 is typical of the anaerobic type, supplying energy mainly by glycolysis.

The aim of the present study was to investigate using isoenzyme patterns, the differences in the type of metabolism between the tissues of obese-hyperglycaemic mice and those of their lean littermates. The tissues studied were skeletal muscle, fat, pancreatic acinar tissue and islets of Langerhans.

\section{Materials and Methods}

\section{a) Experimental groups}

Experiments were carried out on 14 obese-hyperglycaemic mice (with a recessive trait for hyperglycaemia and obesity from the strain obtained from the Institute of Animal Genetics, University of Edinburgh, Scotland, U.K.) - (O-H mice), and on 17 lean littermates of both sexes - ( $\mathrm{N}$ mice $)$, kept under standard conditions. The animals of both groups were $15-18$ weeks old. Before the experiment the animals were starved overnight with free access to water.

\section{b) Tissue procurement}

The animals were killed by hyperextension of the neck. Pancreas, skeletal muscle and fat tissue were removed. Pancreatic islets were isolated from the pancreas by freehand micro-dissection technique [18, 8], and the samples of exocrine pancreas were taken from the remaining tissue, devoid of islets. As the amount of islet tissue obtained from one mouse was small, pooled samples from $2-3$ mice were used, and calculated as one single sample. The skeletal muscle specimens were obtained from the pectoral muscle and those of subcutaneous fat from the abdominal region. All necessary conditions for enzymological investigations were observed. All determinations were made in duplicate.

\section{c) Homogenization and extraction}

Homogenization was carried out in a PotterElvehjem all-glass homogenizer (homogenization of islets in a special microhomogenizer centrifuge tubes
[18] in a barbital buffer; $\mathrm{pH}$ 8.4; ionic strength 0.05 . The ratio of the wet tissue $(\mathrm{g})$ to the volume $(\mathrm{ml})$ was 1:9. The homogenates were centrifuged for $30 \mathrm{~min}$ at $10000 \times g$. All operations were performed at $2^{\circ} \mathrm{C}$. The supernatant was immediately used for further determinations.

\section{d) Total LDH activity assay}

The determination was carried out by spectrophotometric technique as described previously [16]. The activity of $\mathrm{LDH}$ was expressed in standard units (U) per $\mathrm{g}$ of wet tissue.

\section{e) Determination of LDH isoenzyme patterns}

LDH isoenzymes were separated by electrophoresis in an agar gel medium cooled by petroleum spirit according to Wieme's method [22]. Agar used was Difeo Special Agar - Noble.

The preparation of the detection of the Agar layer, incubation of combined agar gel layers, fixation and drying were carried out as described previously [17]. With automatic integration (Kipp and Zonen Densitometer DD2) density curves were recorded. The activity of individual isoenzymes was expressed as the percentage of the total LDH activity (as measured by staining procedure), and this percentage was used to indicate the relative amounts of each $\mathrm{LDH}$ isoenzyme in the material.

Statistical evaluation was made by Student's $t$ test for paired values, the significance level being 0.05 .

Because the amount of total LDH in the supernatant used for the electrophoretic separation can influence the resulting percentages of individual isoenzymes [15], the extracts from fat and muscle of both groups of animals were adjusted to give similar total $\mathrm{LDH}$ activities. These extracts were designated Group A. Some extracts prepared from $\mathrm{N}$ mice islets exhibited very low total LDH activity, and on electrophoretic separation revealed only two main fractions (LDH 4 and LDH 5). In order to compare the LDH isoenzyme patterns of pancreatic tissues of both groups of animals, the corresponding extracts prepared from exocrine and islet tissues of $\mathrm{O}-\mathrm{H}$ mice and from exocrine pancreas of $\mathrm{N}$ mice had to be diluted, and subsequently they also revealed two fractions. These were designated extracts Group B. Furthermore, in order to obtain all the fractions of LDH activity in pancreatie tissues their extracts were subjected to electrophoresis in the highest possible concentrations without standard adjustment of their $\mathrm{LDH}$ activity. Obviously the results so obtained are less accurate, and these were designated extracts Group C.

\section{Results}

\section{Total LDH activity}

The total LDH activity of both the islets and acinar tissue in $\mathrm{N}$ mice was significantly lower than that in O-H mice (Table 1). 
Table 1 also shows that the LDH activity in the acinar tissue compared with that in the islets is about four times in $\mathrm{N}$ mice, and about twice in $\mathrm{O}-\mathrm{H}$ mice.

There was no significant difference in the LDH activity of skeletal muscle or of fat tissue between both groups of animals (Table 1 ). with that in $\mathrm{N}$ mice), the skeletal muscle exhibited a lower LDH 5 percentage in $\mathrm{O}-\mathrm{H}$ mice than in $\mathrm{N}$ mice. The percentages of LDH 1, LDH 2 and LDH 3 were higher in $\mathrm{O}-\mathrm{H}$ mice. All these differences were significant (Table 4). The percentage of LDH 4 was nearly the same in both groups of animals.

Table 1. Lactate dehydrogenase (LDH) activity in pancreatic islets, acinar pancreas, skeletal muscle and fat tissue of $N$ and $O-H$ mice

\begin{tabular}{|c|c|c|c|c|}
\hline \multirow[t]{2}{*}{ Animals } & \multicolumn{4}{|c|}{ LDH activity (U/g wet tissue) } \\
\hline & Islets & Acinar pancreas & Skeletal muscle & Fat tissue \\
\hline $\begin{array}{l}\mathrm{N} \\
\mathrm{O}-\mathrm{H}\end{array}$ & $\begin{array}{c}56 \pm 6^{\mathrm{a}}(9)^{\mathrm{b}} \\
155 \pm 25(9)\end{array}$ & $\begin{array}{ll}236 \pm 24 & (10) \\
372 \pm 32 & (10)\end{array}$ & $\begin{array}{l}4.810 \pm 547(5) \\
3.705 \pm 437(6)\end{array}$ & $\begin{array}{r}111 \pm 18(6) \\
94 \pm 4(5)\end{array}$ \\
\hline $\begin{array}{l}\text { Statistical signif- } \\
\text { icance }(\mathrm{P}) \text { of } \\
\text { differences be- } \\
\text { tween mean } \\
\text { values of } N \text { and } \\
\mathrm{O}-\mathrm{H} \text { mice }\end{array}$ & $+c$ & + & 0 & 0 \\
\hline
\end{tabular}

a values expressed as mean $\perp$ SEM

b the numbers of experiments performed in parenthesis

c $\mathrm{P}<0.05=+\quad \mathrm{P}>0.05=0$

\section{LDH isoenzyme patterns}

In all the examined tissues except those of extract Group B (see Section e in Materials and Methods), five LDH isoenzymes were recorded.

The comparison of isoenzyme pattern between $\mathrm{N}$ and $\mathrm{O}-\mathrm{H}$ mice was as follows:

\section{Pancreatic islets}

In extracts Groups B and C, lower percentages of LDH 4 and higher percentages of LDH 5 were found in islets of $\mathrm{O}-\mathrm{H}$ mice. The differences in both groups of extracts were statistically significant (Tables 2 and 3). The differences in percentages of $\mathrm{LDH} 1, \mathrm{LDH} 2$, and LDH 3 in extracts Group $\mathrm{C}$ were not significant (Table 3).

\section{Pancreatic acinar tissue}

The acinar tissue of $\mathrm{O}-\mathrm{H}$ mice differed from that of $\mathrm{N}$ mice in its LDH 4 and LDH 5 percentages in similar fashion to that of islets. The LDH 1 and LDH 2 percentages appeared to be higher in $\mathrm{O}-\mathrm{H}$ mice than in $\mathrm{N}$-mice. However, the difference between the LDH 1 percentages was not statistically significant whereas the difference between $\mathrm{LDH} 2$ percentages was. $\mathrm{LDH} 3$ percentages of acinar tissue were approximately the same in both groups of animals (Table 2 and 3 ).

\section{Fat tissue}

The percentages of $\mathrm{LDH} 1, \mathrm{LDH} 2, \mathrm{LDH} 3$ and LDH 4 in the fat tissue of $N$ mice were significantly higher than those in $\mathrm{O}-\mathrm{H}$ mice. However, the percentages of LDH 5 were significantly lower (Table 4 ).

\section{Skeletal muscle}

In contrast to the results obtained in all the other tissues (LDH 5 higher in $\mathrm{O}-\mathrm{H}$ mice when compared
Table 2. Lactate dehydrogenase ( $L D H$ ) isoenzymes in the pancreatic islets and acinar tissue of $N$ and $O-H$ mice Extracts used were diluted to standard LDH activity (extracts Group B)

\begin{tabular}{|c|c|c|c|c|}
\hline \multirow[t]{2}{*}{ Tissue } & \multirow[t]{2}{*}{ Animals } & \multirow[t]{2}{*}{$n$} & \multicolumn{2}{|c|}{$\mathrm{LDH}$ isoenzymes $(\%)$} \\
\hline & & & $\overline{\mathrm{LDH}} 4$ & LDH 5 \\
\hline Islets & $\begin{array}{l}\mathrm{N} \\
\mathrm{O} \cdot \mathrm{H}\end{array}$ & $\begin{array}{l}6 \\
6\end{array}$ & $\begin{array}{l}22.3 \pm 1.6^{\mathrm{a}} \\
16.8 \pm 2.0\end{array}$ & $\begin{array}{l}77.7 \pm 1.6 \\
83.2 \pm 2.0\end{array}$ \\
\hline Acinar & $\begin{array}{l}\mathrm{N} \\
0-\mathrm{H}\end{array}$ & $\begin{array}{l}6 \\
5\end{array}$ & $\begin{array}{l}28.7 \pm 2.8 \\
20.0 \pm 2.5\end{array}$ & $\begin{array}{l}71.3 \pm 2.8 \\
80.0 \pm 2.5\end{array}$ \\
\hline
\end{tabular}

Statistical significance of differ-

ence between mean LDH

isoenzyme percentages in

$\mathrm{N}$ pancreatic islets

O.H pancreatic islets

$\mathrm{N}$ acinar tissue

$\mathrm{O}-\mathrm{H}$ acinar tissue

$\mathrm{N}$ pancreatic islets

$\mathbf{N}$ acinar tissue

O-H pancreatic islets

$\mathrm{O}-\mathrm{H}$ acinar tissue

$\begin{array}{ccc}+b & + \\ + & + \\ + & + \\ + & +\end{array}$

a Values expressed as mean \pm SEM

b $P<0.05=+$

Fig. 1 shows simultaneous comparison of LDH isoenzyme patterns from four kinds of tissues examined in both groups of animals.

Pancreatic islets and acinar tissue in $\mathrm{N}$ and in $\mathrm{O}-\mathrm{H}$ mice

The group $\mathrm{C}$ of extracts, which were not adjusted in a standard manner, revealed all five isoenzymes, but as mentioned above with less accurate percentages. Here the percentage of LDH 4 in islets when compared with that in acinar tissue was lower, whereas that of LDH 5 was higher in both groups of animals. The difference in $\mathrm{LDH} 4$ percentages was significant in 


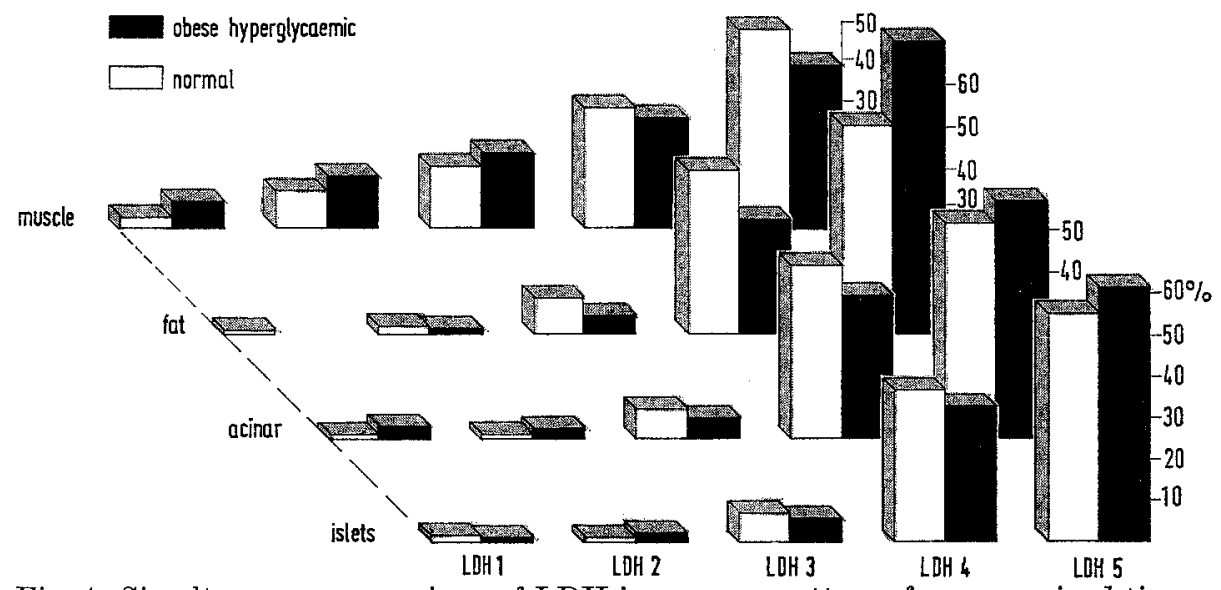

Fig. 1. Simultaneous comparison of LDH isoenzyme patterns from examined tissues of $\mathrm{N}$ and $\mathrm{O}-\mathrm{H}$ mice

Table 3. Lactate dehydrogenase (LDH) isoenzymes in the pancreatic islets and acinar tissue of $N$ and $O$. $H$ mice (extracts - Group $C$ )

\begin{tabular}{|c|c|c|c|c|c|c|c|}
\hline \multirow[b]{2}{*}{ Tissue } & \multirow[b]{2}{*}{ Animals } & \multirow[b]{2}{*}{$\mathrm{n}$} & \multicolumn{5}{|c|}{$\mathrm{LDH}$ isoenzymes (\%) } \\
\hline & & & LDH 1 & LDH 2 & LDH 3 & LDH 4 & LDH 5 \\
\hline Islets & $\begin{array}{l}\mathrm{N} \\
\mathrm{O}-\mathrm{H} \\
\mathrm{N} \\
\mathrm{O}-\mathrm{H}\end{array}$ & $\begin{array}{l}4 \\
6 \\
7 \\
6\end{array}$ & $\begin{array}{l}0.7 \pm 0.3^{\mathrm{a}} \\
0.7 \pm 0.4 \\
0.4 \pm 0.3 \\
2.2+1.0\end{array}$ & $\begin{array}{l}1.0 \pm 0.5 \\
1.5 \pm 0.7 \\
0.4 \pm 0.2 \\
2.2 \pm 0.6\end{array}$ & $\begin{array}{l}6.3 \pm 0.8 \\
5.5 \pm 1.0 \\
5.7 \pm 1.1 \\
4.8 \pm 0.7\end{array}$ & $\begin{array}{l}36.7 \pm 1.0 \\
31.1 \pm 1.3 \\
41.9 \pm 0.3 \\
34.2 \pm 1.1\end{array}$ & $\begin{array}{l}55.3 \pm 0.7 \\
61.2 \pm 1.5 \\
51.6 \pm 1.5 \\
56.6 \pm 1.1\end{array}$ \\
\hline \multicolumn{8}{|c|}{$\begin{array}{l}\text { Statistical significance of } \\
\text { difference between mean } \mathrm{LDH} \\
\text { isoenzyme percentages in }\end{array}$} \\
\hline \multicolumn{2}{|c|}{$\begin{array}{l}\mathrm{N} \text { pancreatic islets } \\
\mathrm{O}-\mathrm{H} \text { pancreatic islets }\end{array}$} & \} & $0^{\mathrm{b}}$ & 0 & 0 & + & + \\
\hline \multicolumn{2}{|c|}{$\begin{array}{l}\text { N acinar pancreas } \\
\mathrm{O}-\mathrm{H} \text { acinar pancreas }\end{array}$} & \} & 0 & + & 0 & + & + \\
\hline \multicolumn{2}{|c|}{$\begin{array}{l}N \text { pancreatic islets } \\
N \text { acinar pancreas }\end{array}$} & ? & 0 & 0 & 0 & + & 0 \\
\hline \multicolumn{2}{|c|}{$\begin{array}{l}\text { O-H pancreatic islets } \\
\text { O-H acinar pancreas }\end{array}$} & \} & 0 & 0 & 0 & 0 & + \\
\hline
\end{tabular}

a Values expressed as mean \pm SEM

b $P<0.05=+\quad P>0.05=0$.

Table 4. Lactate dehydrogenase (LDH) isoenzymes in the fat tissue and skeletal muscle of $N$ and $\mathrm{O}-\mathrm{H}$ mice (extracts-Group A)

\begin{tabular}{|c|c|c|c|c|c|c|c|}
\hline \multirow[b]{2}{*}{ Tissue } & \multirow[b]{2}{*}{ Animals } & \multirow[b]{2}{*}{$\mathrm{n}$} & \multicolumn{5}{|c|}{$\mathrm{LDH}$ isoenzymes (\%) } \\
\hline & & & $\mathrm{LDH} 1$ & LDH 2 & LDH 3 & LDH 4 & $\mathrm{LDH} 5$ \\
\hline$\overline{\text { Fat }}$ & $\begin{array}{l}\mathrm{N} \\
\mathrm{O}-\mathrm{H}\end{array}$ & $\begin{array}{l}5 \\
5\end{array}$ & $\begin{array}{l}0.6 \pm 0.3^{\mathrm{a}} \\
0.0 \pm 0\end{array}$ & $\begin{array}{l}1.2 \pm 0.7 \\
0.2 \pm 0.1\end{array}$ & $\begin{array}{l}7.8 \pm 1.8 \\
3.2 \pm 0.1\end{array}$ & $\begin{array}{l}39.6 \pm 1.2 \\
26.4 \pm 4.4\end{array}$ & $\begin{array}{l}50.8 \pm 2.0 \\
70.2 \pm 4.7\end{array}$ \\
\hline Skeletal & $\mathbf{N}$ & 5 & $2.6 \pm 0.5$ & $\begin{array}{r}8.0 \pm 0.5 \\
18 \pm 0.8\end{array}$ & $14.0 \pm 1.1$ & $28.0 \pm 1.3$ & $\begin{array}{l}47.4 \pm \mathbf{2 . 6} \\
\mathbf{3 9 . 0} \mathbf{1 . 3}\end{array}$ \\
\hline Muscle & $\mathrm{O}-\mathrm{H}$ & 5 & $5.8 \pm 1.0$ & $11.8 \pm 0.8$ & $17.2 \pm 0.3$ & $26.2 \pm 0.7$ & $39.0 \pm 1.3$ \\
\hline \multicolumn{8}{|c|}{$\begin{array}{l}\text { Statistical significance of } \\
\text { difference between mean LDH } \\
\text { isoenzyme percentages in }\end{array}$} \\
\hline $\begin{array}{l}N \text { fat } \\
\mathrm{O}-\mathrm{H} \text { fat }\end{array}$ & & ) & $t^{b}$ & + & + & + & + \\
\hline $\begin{array}{l}\mathrm{N} \text { muscl } \\
\mathrm{O}-\mathrm{H} \mathrm{mu}\end{array}$ & & 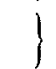 & + & + & + & 0 & + \\
\hline
\end{tabular}

a Values expressed as mean \pm SEM

b $P<0.05=+\quad P>0.05=0$ 
$\mathrm{N}$-mice, but in $\mathrm{O}-\mathrm{H}$ mice it was $\mathrm{LDH} 5$ which was significantly different. The percentages of $\mathrm{LDH} 1$, LDH 2 and LDH 3 in islets were not significantly different from those of acinar tissue in either $\mathrm{N}$ or $\mathrm{O}-\mathrm{H}$ mice, although the percentages of LDH 1 and LDH-2 in acinar tissue of O-H mice appeared to be higher than in islets (Table 3). In group B of extracts, which were adjusted a standard manner, only two fractions, but with more accurate percentages, were separated. As in Group Cof extracts, the islets exhibited a lower percentage of LDH 4 and higher percentage of LDH 5 in both groups of animals, but all differences of percentages were significant (Table 2).

\section{Discussion}

The present investigation shows that the total LDH activity in islets of $\mathrm{O}-\mathrm{H}$ mice is higher than that of $\mathrm{N}$ mice. It is known that the islets of O-H mice are composed of more than $90 \%$ of beta cells and these cells are in a hypersecretory state $[7,11]$. This characteristic of islets of O-H mice might serve as an explanation for the higher total LDH activity, but our data revealed that acinar tissue of $\mathrm{O}-\mathrm{H}$ mice also displayed a higher total LDH activity when compared with that of $\mathrm{N}$ mice. This may indicate that the increase of total $\mathrm{LDH}$ activity in islets is due to the general increase of $\mathrm{LDH}$ activity in the whole of the pancreas in $\mathrm{O}-\mathrm{H}$ mice. It might be mentioned that the hypersecretory state of pancreatic beta cells produced by tolbutamide treatment did not show any increase in their LDH activity [12]. Nevertheless, when comparing the total LDH activity of the islets with that of acinar tissues, it becomes obvious that in $\mathrm{O}-\mathrm{H}$ mice the islets displayed relatively higher activity than in $\mathrm{N}$ mice. This suggests that more than one factor is responsible for this increase in LDH activity in islets.

In contrast to the pancreatic tissues, no significant differences were found between the total LDH activity of either fat or muscle of $\mathrm{O}-\mathrm{H}$ mice and that of the corresponding tissues of $\mathrm{N}$ mice.

The conclusions derived from these results using the above method of LDH activity assay, i.e. the same concentration of substrate for every determination, should be considered valid because the LDH 1 and LDH $\mathbf{5}$ isoenzymes in the examined tissues were not present in greatly differing amounts.

An investigation of their characteristic LDH isoenzyme patterns has indicated that the anaerobic type of metabolism (energy gained mainly by glycolysis) is prevalent in all examined tissues. The present data extend those of previous workers [10] on islets and acinar tissue, who examined only the $\mathrm{O}-\mathrm{H}$ mice. By comparing the LDH isoenzyme patterns in the corresponding tissues from $\mathrm{N}$ and $\mathrm{O}-\mathrm{H}$ mice it becomes apparent that the islets, the acinar tissue and fat tissue of $\mathrm{O}-\mathrm{H}$ mice displayed higher proportions of LDH 5. This indicates that these tissues tend to be more equipped for anaerobic type of metabolism. In contrast, the skeletal muscle of $\mathrm{O}-\mathrm{H}$ mice surprisingly showed higher proportions of LDH 1 and lower proportions of $\mathrm{LDH} 5$ when compared with that of $\mathrm{N}$ mice. This suggests that the skeletal muscle in contrast to the other examined tissues displays a greater tendency towards aerobic type of metabolism in O-H mice. This means schematically the change in prevalence (or relative prevalence) of either the citric acid cycle (increase) or the glycolytic pathway (decrease).

LDII 1 and LDH 5 play different roles in the relation between citric acid cycle and glycolysis. LDH 1 (due to its kinetic properties) aids in keeping glycolysis at a rate sufficient to maintain the citric acid cycle by the pyruvate supply. Increased demands on energy supply cannot be provided by glycolysis because LDH 1 acts as a limiting factor of glycolysis. The intensification of glycolysis results in TDH 1 inhibition (due to the increased concentration of pyruvate), and less NAD, created by the reaction pyruvate to lactate, is available, thus diminishing the rate of glycolysis. When the increased demands on energy supply are provided in the presence of LDH 1 by the intensification of the citric acid cycle it is apparent that glucose cannot be the main fuel and alternative fuels (fatty acids) are used.

On the other hand, LDH 5 favours the glycolytic pathway (LDH 5 is not inhibited by high concentrations of pyruvate). Increased demands on energy supply in the presence of LDH 5 cannot be provided by the intensification of citric acid cycle. LDH 5 is activated by citric acid cycle metabolites [6]. Increased concentration of these metabolites will accelerate the reaction pyruvate to lactate, less pyruvate is then available to maintain the citric acid cycle.

Considering the role of $\mathrm{LDH} 1$ and $\mathrm{LDH} 5$ in the relation of glycolysis and the citric acid cycle, it becomes apparent that the finding of a relative increase of LDH 1 and a decrease of LDH 5 in the skeletal muscle of $\mathrm{O}-\mathrm{H}$ mice indicates the relative prevalence of the citric acid cycle. This suggestion is consistent with the finding of the high activity of NADP-isocitrate dehydrogenase in the skeletal muscle [9] of O-H mice. Furthermore, this suggestion could be correlated with the shift from glucose to fatty acids as the main source of energy. This is in agreement with the opinion that in diabetic muscle a decreased glucose uptake due to the increased concentration of fatty acids takes place [19]. It is also in agreement with the proposition that alterations in the intermediary metabolism of glucose and fatty acids in the skeletal muscle could serve as an explanation for the marked lethargy of $\mathrm{O}-\mathrm{H}$ mice $[3,4]$.

\section{References}

1. Appella, E.C., Markert, C.L.: Dissociation of lactate dehydrogenase into subunits with guanidine hydrochloride. Biochim. biophys. Res. Comm. 6, 171-176 (1961). 
2. Cahn, R.D., Kaplan, N.O., Levine, L., Zwilling, E. Nature and development of lactic dehydrogenases. Science 136, 962-969 (1962).

3. Christophe, J.: Contribution a la Biochimie des obesites Experimentales, p. 1-220. Paris and Brus. sels: Editions Malo ne et Arscia 1961.

4. - Winand, J., Furnella, J. : The obese-hyperglycemic syndrome in Bar Harbor mice. In Diabetes, Proc. 6th Congress. Int. Fed. Amsterdam, Excerpta Medica Foundation 788-799, 1969.

5. Dawson, D.M., Goodfriend, T.L., Kaplan, N.O.: Lactic dehydrogenases: functions of the two types. Science 143, 929-933 (1964).

6. Fritz, P.J.: Rabbit muscle lactate dehydrogenase 5; a regulatory enzyme. Science 143, 364-366 (1965).

7. Gepts, W., Christophe, J., Mayer, J.: Pancreatic islets in mice with the obese-hyperglycemic syndrome; Lack of effect of carbutamide. Diabetes 9, 63-69 (1960).

8. Hellerström, C.: A method for the microdissection of the intact pancreatic islets of mammals. Acta. endocr. (Kbh). 45, 122-132 (1964).

9. Hellman, B.: Some metabolic aspects of the obesehyperglycemic syndrome in mice. Diabetologia 3, 222-229 (1967).

10. - Taljedal, I.B.: Quantitative studies on isolated pancreatic islets of mammals. Endocrinology 81, $125-131$ (1967).

11. - Brolin, S.E., Hellerström, C., Hellman, K.: The distribution pattern of the pancreatic islets volume in normal and obese-hyperglycemic mice. Acta endocr. (Kbh). 36, 609-616 (1961).

12. Kissane, J.M., Brolin, S.E.: Enzymatic activity of pancreatic islets and acini in normal and tolbutamide treated rats. J. Histochem. Cytochem. 11, 197-201 (1963).

13. Latner, A.L., Skillen, A.W.: Isoenzymes in Biology and Medicine, pp. 4-42. London and New York: Academic Press 1968.
14. Markert, C.L., Møller, F.: Multiple forms of enzymes: tissue, ontogenetic and species specific patterns. Proc. nat. Acad. Sci. U.S.A. 45, 753-763 (1959)

15. Prochazka, B., Barta, V.: Unpublished data.

16. - Kohout, J., Korbova, L., Jirasek, V., Barta, V., Prochazkova, M.: Differences in lactate dehydrogenase isoenzyme patterns in experimental lesions of the stomach. Canad. J. Biochem. 46, 129-133 (1968).

17. - - - - Schlupek, A., Slezak, Z.: Differences in lactate dehydrogenase isoenzyme patterns in fundus and pylorus of the rat stomach. Gastroenterology 54, $60-64$ (1968).

18. Qureshi, M.A.: Morphological and Metabolic investigations on the isolated pancreatic islets of two teleost species, normal and obese-hyperglycemic mice. Birmingham, U.K.: Ph. D. Thesis, University of Aston in Birmingham 1968.

19. Randle, P.J., Newsholme, E. A., Garland, P.B. : Regulation of glucose uptake by muscle: 8 . Effects of fatty acids, ketone bodies and pyruvate, and of alloxan diabetes and starvation, on the uptake and metabolic fate of glucose in rat heart and diaphragm muscles. Biochem. J. 93, 652-665 (1964).

20. Vesell, E.S., Bearn, A.G.: Localization of lactic dehydrogenase activity in serum fractions. Proc. Soc. exp. Biol. (N. Y.) 94, 96-99 (1957).

21. Wieland, T., Pfleiderer, G.: Nachweis der Heterogenität von Milchsäure-dehydrogenasen verschiedenen Ursprungs durch Trägerelectrophorese. Biochem. Z. 329, $112-116$ (1957).

22. Wieme, R.J.: An improved technique of agar-gel electrophoresis on microscope slides. Clin. chim. Acta 4, 317-321 (1959).

23. Wilkinson, J.H.: Isoenzymes, pp. 43-83. London: E \& F. N. Spon Ltd. 1965.

B. Prochazka, M.D., C.Sc. Dept. of Biological Sciences

The University of Aston in Birmingham

Gosta Green, Birmingham 4,

United Kingdom 